\title{
HAS THE LAW NUMBER 24 YEAR 2007 ACCOMMODATED RECOVERY FROM PSYCHOLOGICAL IMPACT FOR VICTIMS?
}

Oleh :

\author{
Eddie Imanuel Doloksaribu
}

Lecturer Faculty of Law

The Atma Jaya Catholic University of Indonesia

eddie.ds@atmajaya.ac.id

\begin{abstract}
ABSTRAK
Berbagai bencana terjadi di Indonesia, menurut hukum, arti dari bencana adalah terjadinya serangkaian kejadian yang mengancam dan mengganggu kehidupan dan mata pencaharian masyarakat yang disebabkan oleh faktor alam dan / atau faktor non-alam atau disebabkan oleh faktor manusia yang mengakibatkan adanya korban, kerusakan lingkungan, kerusakan infrastruktur dan adanya dampak psikologis. Dalam setiap terjadinya bencana, pemerintah wajib melakukan perannya dalam upaya untuk memulihkan dampak dari bencana tersebut. Kewajiban pemerintah tersebut sebagai bentuk tanggung jawab negara kepada rakyatnya seperti yang dinyatakan dalam Undang-undang Dasar 1945 dan dalam Pasal 3 Deklarasi Universal Hak Asasi Manusia di mana dinyatakan bahwa setiap orang memiliki hak atas kehidupan, kebebasan dan keselamatan sebagai individu. Pemerintah Indonesia telah mengundangkan Undang-Undang Republik Indonesia Nomor 24 Tahun 2007 tentang Penanggulangan Bencana sebagai dasar hukum hukum dan pedoman dalam penanganan bencana. Setelah berlakunya undang-undang ini, diharapkan adanya koordinasi yang lebih baik dalam manajemen bencana.
\end{abstract}

\section{Kata kunci: Manajemen Bencana, Dampak Psikologis, Korban.}

\begin{abstract}
Various disasters occurred in Indonesia. According to the law, disaster is a series of events that threaten and disrupt the lives and livelihoods caused by natural and/or non-natural factors or resulting from human factors that lead to casualties; environmental and infrastructure damage; and the psychological impact. In any disaster, the government must do its part in efforts to recover from the implications of the catastrophe. The government's obligation as a form of state responsibility to its people are stated in Constitution and Article 3 of the Universal Declaration of Human Rights which states that everyone has the right to life, liberty, and security as an individual. The Indonesian government has enacted the Law of the Republic of Indonesia Number 24 Year 2007 on Disaster Management as the basis of the laws and guidelines in disaster management. After the entry into force of this law, it is expected that coordination in disaster management will get better.
\end{abstract}

\section{Keywords: Disaster Management, Psychological Impact, Casualties}

\section{A. Introduction}

Nowadays, the sense of insecurity for most people arises not so much from threats of war or external aggression as from threats of human deprivation, but people concerned with security relating to their income, job, education, and health. ${ }^{1}$ That attention was explained in Human Development Report Year 1994 which has identified two essential

\footnotetext{
${ }^{1}$ See also Bo Asplund and Romeo A. Reyes, Human Security, Human Development and the Millenium Development Goals, Jurnal Hukum Internasional (Indonesian Journal of International Law), Volume 1 Number 1 October 2003, ISSN: 1693-5594, Centre for International Studies, Faculty of Law University of Indonesia, P. 35.
}

28 HAS THE LAW NUMBER 24 YEAR 2007 ACCOMMODATED RECOVERY FROM PSYCHOLOGICAL IMPACT FOR VICTIMS? 
aspects of Human Security, such as "freedom from fear and freedom from want."2 Human Security is distinct and should not be confused with the traditional concept of national security. Human security is linked to human development for the simple reason that the latter leads to the former. ${ }^{3}$

Human Security has given more attention to the person as an individual. The target of human security has been established at Millennium Summit 2000 which was followed by 147 Head States. That Declaration called as Millennium Development Goals (MDGs). ${ }^{4}$ MDGs have 8 (eight) main goals, such as: ${ }^{5}$

1. Eradicate extreme poverty and hunger;

2. Achieve universal primary education;

3. Promote gender equality and empower women;

4. Reduce child mortality;

5. Improve maternal health

6. Combat HIV/AIDS, malaria and other diseases;

7. Ensure environmental sustainability;

8. Develop a global partnership for development.

The declaration was embedded with certain shared fundamental values although underlying differences persist. Developed countries place greater emphasis on promoting values such as good governance, the rule of law and human rights. ${ }^{6}$

The problem on disaster especially on natural disaster such as the natural disaster in Haiti, Chile and also in Indonesia, is one of the serious challenges which related to the implementation of human security.

Natural disaster in Indonesia is a general thing for Indonesia. Indonesia is an archipelago state which is the biggest in the world, it is located on equator line, and at a cross position between two Oceans (The Indian Ocean and the Pacific Ocean), and also between two Continents (Asia and Australia). This position has a strategic point especially in related to the biological diversity and natural resources, but this location makes Indonesia to be included in Pacific ring of fire which is dangerous toward natural disasters such as an earthquake, a tsunami, and a volcano explosion. ${ }^{7}$ In the last decade, the occurrences of natural disasters in Indonesian territories have been intensified. The latest disaster reported was an Earthquake of 7.6 SR in West Sumatera which has caused material and immaterial loss to the people, including the death of hundreds of people. Natural disasters can happen anytime, especially as Indonesia is a disaster prone territory. An enthusiasm of disaster management in Indonesia only takes place during the time of disaster, in the forms of humanitarian aid mobilization such as money collecting, food aid, voluntaries aid, etc. However, after the disaster ends, the government's and society's attention also slowly ends. ${ }^{8}$

In every disaster, the government conducts its role in the effort to recover the impact. The government is obliged to perform its role as a form of the state's responsibility

\footnotetext{
${ }^{2}$ Syahrial Loetan, Millenium Development Goal (MDG) dan Program Pembangunan Nasional di Indonesia, Jurnal Hukum Internasional (Indonesian Journal of International Law), Volume 1 Number 1 October 2003, ISSN: 1693-5594, Centre for International Studies, Faculty of Law University of Indonesia, P. 61.

${ }^{3}$ Asplund and Romeo A. Reyes, Op. Cit., P. 38.

${ }^{4}$ Syahrial Loetan, Op.Cit. P. 62.

${ }^{5}$ Ibid and see also Asplund and Romeo A. Reyes, Op. Cit., P. 40.

${ }^{6}$ Djauhari Oratmangun, Human Development snd Human Security: A Journey towards a Humane Global World, Jurnal Hukum Internasional (Indonesian Journal of International Law), Volume 1 Number 1 October 2003, ISSN: 1693-5594, Centre for International Studies, Faculty of Law University of Indonesia, P. 51.

${ }^{7}$ Natalia Yeti Puspita, Legal Analysis on Human Rights Protection in times of Natural Disasters and Its Implementation In Indonesia, Working Paper for Asian Law Institute Seminar, National University of Singapore, 12 February 2010, P. 2. ${ }^{8}$ Ibid.
} 
to its people as mentioned in Article 3 Universal Declaration of Human Rights that everyone has the right to life, liberty and security of person, and also in the Constitution of The Republic Indonesia (Undang-Undang dasar 1945). The Indonesian government has established The Law of Republic Indonesia Number 24 Year 2007 Concerning Disaster Management as the fundamental law and legal guidance in the disaster management. After the enactment of this law, there is better coordination in disaster management than before.

The Law is divided into three phases of disaster management, which are: predisaster phase, emergency phase, and after- disaster phase. As implementation of this law, if disasters happen, the government must conduct disaster management. In fact, the government's efforts are more focused on the physic recovery (infrastructure) rather than on the psychological aspects of the disaster victims. Even though some psychological recovery is provided, they are still far from ideal. When the period of emergency, disaster management decided by the government is over, all aids will be terminated, including psychological recovery aids for disaster victims. The fact that psychological recovery is needed for a longer and more indefinite period was never taken into consideration.

In this paper, writers would like to analyze "Has the Law of Republic Indonesia Number 24 Year 2007 Concerning Disaster Management Accommodated a Recovery Effort of Psychological Impact of Disaster Victims in Indonesia?"

\section{B. Discussion}

\section{The View Of Natural Disaster Management}

a. Definition of Natural Disaster

A natural disaster is the effect of a natural hazard (e.g. flood, tornado, volcano eruption, earthquake, or landslide) that affects the environment, and leads to financial, environmental and human losses. The resulting loss depends on the capacity of the population to support or resist the disaster, and their resilience. This understanding is concentrated in the formulation: "disasters occur when hazards meet vulnerability." ${ }^{9} \mathrm{~A}$ natural hazard will hence never result in a natural disaster in areas without vulnerability, e.g. strong earthquakes in uninhabited areas. The term natural has consequently been disputed because the events simply are not hazards or disasters without human involvement. ${ }^{10}$ On the other hand, United Nations Development Programme (UNDP) stated that natural disaster was a serious disruption of the functioning of society, causing widespread human, material, or environmental losses which exceed the ability of affected society to cope by using only its resources. ${ }^{11}$ Natural disaster also refers to the consequences of events triggered by such natural hazards as earthquakes, volcanic eruptions, landslides, tsunamis, floods and drought that overwhelm local response capacity. Such disasters seriously disrupt the functioning of a community or a society causing widespread human, material, economic or environmental losses, which exceed the ability of the affected community or society to cope by using its resources. ${ }^{12}$

b. The Cause of Natural Disasters

\footnotetext{
${ }^{9}$ Ibid.

${ }^{10}$ Ibid.

${ }^{11}$ A.B. Susanto, Disaster Management di Negeri Rawan Bencana, PT. Aksara Grafika Pratama, Jakarta, 2006, P. 2.

12 Human Rights and Natural Disasters, Operational Guidelines and Field Manual on Human Rights Protection in Situations of Natural Disasters, Brookings-Bern Project on Internal Displacement, See also IASC IDP Policy, Annex 3 (referring to Sylvie Giossi Caverzasio (ed), Strengthening Protection in War - A Search for Professional Standards, Geneva, ICRC, 2001, P.6., See also the glossary of the International Society for Disaster Reduction; http://www.unisdr.org/eng/library/lib-terminologyeng\% 20home.htm (16 May 2007).
}

30 HAS THE LAW NUMBER 24 YEAR 2007 ACCOMMODATED RECOVERY FROM PSYCHOLOGICAL IMPACT FOR VICTIMS? 
There are a lot of causes of natural disasters. Based on culture and faith of the traditional community, disasters appear as a natural stabilization and also as a punishment for human being which violates community rules. Another theory stated that natural disaster happened because of a natural phenomenon. Some see natural disasters as nature's way of some great system of checks and balances, designed to control the world's population. Finally, this argument makes an opinion that natural disaster is God's Will. However, a natural disaster can happen because of a natural phenomenon and also human involvement.

\section{c. The Types of Natural Disasters}

There are many types of natural Disasters. Earthquake is effectively a self defining term - the Earthquakes, the Earth shakes, and we feel the vibrations. ${ }^{13}$ On the other hand, an earthquake is defined as the sudden, fast shaking of the earth, caused by the breaking and shifting of subterranean rock. ${ }^{14}$ Extreme Heat, dry weather may occur on long or short timescales. As continents drift and ocean basins open and close, large regions may be cut off from moisture supplies and kept in long - term desert conditions. ${ }^{15}$ So, extreme heat is defined as a heat wave which has extended the period of extreme heat often with high humidity. ${ }^{16}$ Floods, downpour with high rainfall intensity can cause floods. Global warming is considered to cause floods. Hurricanes - Hurricanes are severe tropical storms that are formed in the southern Atlantic Ocean, Caribbean Sea, Gulf of Mexico and in the eastern Pacific Ocean. ${ }^{17}$

A hurricane is the only natural disaster that is given a human name. For example, Camille, Hugo, Iniki, Mitch, Pauline, etc. hurricanes are large tropical cyclones. They are heat engines that convert the heat energy of the tropical ocean into winds and waves. ${ }^{18}$ Landslides and Debris Flow - Landslides, also known as mudslides or debris flow, occur in all U.S. states and territories. ${ }^{19}$ Thunderstorms and Lightning - All thunderstorms produce lightning, and all of them are potentially dangerous. Those dangers can include tornadoes, high winds, hail, wildfires and flash flood. ${ }^{20}$ Thunderstorms occur where warm, moist air has absorbed enough heat and moisture to be significantly less dense than the surrounding air. ${ }^{21}$ Tornadoes - Tornadoes are nature's most violent storms. They can appear suddenly without warning and can be invisible until dust and debris are picked up, or a funnel cloud appears. $^{22}$ Tsunamis - Tsunamis, also known as seismic sea waves. Volcanoes - When pressure builds up within a volcano's molten rock, it has the potential to erupt, sending lava flows, poisonous gas and flying rock and ash that can sometimes spread hundreds of miles downwind. ${ }^{23}$ Winter Storms and Extreme Cold - That could mean snow or subfreezing temperatures, as well as strong winds or even ice or heavy rain storm. ${ }^{24}$

\section{d. The Impact of Natural Disasters}

\footnotetext{
${ }^{13}$ Patrict L. Abbott, Natural Disasters, Fourth Edition, the McGraw-Hill, 2004, P. 61

${ }^{14} \mathrm{See}$ http://en.wikipedia.org/wiki/Natural_disaster, retrieve on 26 October 2009.

${ }^{15}$ Patrict L. Abbott, Op. Cit., P. 299.

${ }^{16}$ See http://en.wikipedia.org/wiki/Natural_disaster, retrieve on 26 October 2009.

${ }^{17}$ Ibid

${ }^{18}$ Patrict L. Abbott, Op. Cit., P. 302.

${ }^{19}$ See http://en.wikipedia.org/wiki/Natural_disaster, retrieve on 26 October 2009

${ }^{20}$ Ibid

${ }^{21}$ Patrict L. Abbott, Op. Cit., P. 283.

${ }^{22}$ See http://en.wikipedia.org/wiki/Natural_disaster, retrieve on 26 October 2009

${ }^{23}$ Ibid.

${ }^{24}$ See http://www.ways2cope.com/Articles/Disaster/Disaster\%20-\%20natural\%20disaster.aspx, retrieve on 26 October 2009
} 
Natural disasters always cause loss than an advantage. This loss affects all the human life, such as a physic impact, a mental health impact, economic consequences, a social and a culture impact. The physic effect is the death of people and others, injury victims, buildings destructions, environmental damages, etc. The Psychic impact is a trauma which is suffered by natural disasters victims. A.B. Susanto (Indonesian disaster management expert), stated that there are some factors which can make a worse natural disaster, among other: ${ }^{25}$ Poverty- a theory said that poverty has correlation with failure. Poverty makes a society close to natural disaster. Population growth- there are a lot of victims in the territory which has dense of the population rather than in territory which has rare of the population. Urbanization - transfer of population from village to city make new problems related to environmental management.

The Population quantities which increase in a city make land more crowded, and there is no choice for people to stay in a natural disaster prone territory such as in a riverside. The environmental destructions- the environmental which are damaged can cause natural disasters. Such as illegal logging, rubbish throwing in the river can cause floods. Lacks of awareness and information - lacks knowledge and information on a natural disaster prone territory in Indonesia make some victims in time of disaster increase. Lacks of legal enforcement - the awareness of society on a natural disasters knowledge without a legal enforcement can make disaster management can not be conducted.

\section{International Regulations On Disaster Management}

Currently, there is no well-recognized and comprehensive regulation which identifies internationally agreed rules, principles, and standards for the protection and assistance of people affected by the natural disaster which is legal binding. And also, many international disaster response operations are subject to ad-hoc rules and systems, which vary dramatically from country to country and impede the provision of fast and efficient assistance-putting lives and dignity at risk. ${ }^{26}$

There are some existing relevant international legal instruments related to disaster management, among others: ${ }^{27}$

1.Convention establishing an international relief union of 1927;

2. Convention on Assistance in the case of nuclear accident or radiological emergency of 1986;

3. Convention on early notification of a nuclear accident of 1986;

4.Council's of Europe Agreement on the Prevention of, Protection against, and Organization of Relief in Major Natural and Technological Disasters of 1987;

5.Convention on Temporary Admission of 1990 (in particular Annex B.9 concerning goods imported for humanitarian purposes);

6.Inter-American Convention to Facilitate Disaster Assistance of 1991;

7.The Tampere Convention on the Provisions of Telecommunication Resources for Disaster Mitigation and Relief Operations of 1998.

8. The International Convention on the Simplification and Harmonization of Customs Procedures as amended in 1999.

9.Framework Convention on Civil Defense Assistance of 2000.

10. The "Seville Agreement" on the Organization of International Activities of the Components of the International Red Cross and Red Crescent Movement of 1997.

\footnotetext{
${ }^{25}$ A.B. Susanto, Op. Cit., P. $4-8$.

${ }^{26}$ DR I.B.R. Supancana, International Disaster Response Law, Rules and Principles (IDRL) Programme of the International Federation of Red Cross and Red Crescent Societes (IFRCS), P.1, see also International Disaster Response Law (IDRL) Appeal No. 01.100/2004, page 1 and Compare to David P Fidler, "The Indian Ocean Tsunami and International Law", ASIL Insight, 2005, page 1-2.

${ }^{27}$ Ibid, P.3-4.
}

32 HAS THE LAW NUMBER 24 YEAR 2007 ACCOMMODATED RECOVERY FROM PSYCHOLOGICAL IMPACT FOR VICTIMS? 
Other relevant legal documents, including but not limited to: ${ }^{28}$

1.Charter on Cooperation to Achieve the Coordinated Use of Space Facilities in the Event of Natural or Technological Disaster of 2000.

2.The statutes of the International Red Cross and Red Crescent Movement as amended in 1995.

3.The Principles and Rules of Red Cross and Red Crescent in Disaster Relief as amended in 1995.

4. The Supplementary measures to enhance the implementation of the Seville Agreement of 2005.

5. The Hyogo Framework for Action of 2005.

6. The measures to Expedite International Relief of 1977.

7.UNGA Resolution 46/182 of 1991.

8.UNGA Resolution 57/150 of 2002.

Below are other regulations which are not bound but could be guidance for the people who work in a natural disaster:

1. Inter-Agency Standing Committee Operational Guidelines on Human Rights and Natural Disasters (2006).

2. Guiding Principles on Internal Displacement (1998).

3. Code of Conduct for International Red Cross and Red Crescent Movement and NGOs in Disaster Relief (1994)

4. Sphere Project Handbook and Humanitarian Charter.

In related to human rights protection in times of natural disasters, there are fundamental principles of human rights protection which are regulated. In the frame of the human rights protection in time of natural disaster, the protection is not limited to securing the survival and physical security of those affected by natural disasters. Protection encompasses all relevant civil and political as well as economic, social and cultural rights guarantees - attributed to them by international human rights and, where applicable, international humanitarian law. Although all human rights are fundamentally interrelated, for practical reasons, these rights can be divided into four groups, namely: ${ }^{29}$ (A) rights related to physical security and integrity (e.g. protection of the right to life and the right to be free from assault, rape, arbitrary detention, kidnapping, and threats concerning the above); (B) rights related to the core necessities of life (e.g. the rights to food, drinking water, shelter, adequate clothing, adequate health services, and sanitation); (C) rights related to other economic, social and cultural protection needs (e.g. the rights to have access to education and work as well as to receive restitution or compensation for lost property); and (D) rights related to other civil and political protection needs (e.g. the rights to religious freedom and freedom of speech, personal documentation, political participation, access to courts, and freedom from discrimination).

The first two groups of rights are most relevant during the emergency, life-saving phase. Only the full respect of all categories of rights, however, can ensure adequate protection of the human rights of those affected by natural disasters, including the displaced. $^{30}$

In the disaster management, at least there are three phases and needs which are applied:

a. The need to get information $=$ pre- natural disaster phase

\footnotetext{
28 Ibid.

${ }^{29}$ Human Rights and Natural Disasters, Op. Cit., P. 8.

30 Ibid., and See also Report of the Representative of the Secretary-General on the Human Rights of Internally Displaced Persons, E/CN.4/2006/71, paragraphs 4-8
} 
In this phase, the society which stays in a natural disaster prone territory must get good information about natural disaster. In connection with this phase, education, training on natural disaster and also preparing of evacuation locations are needed in this phase.

b. The need to ensure non-discrimination in natural disasters condition $=$ emergencynatural disaster phase

In this phase, there is no discrimination to distribute assistance. Definition of nondiscrimination in this meaning is that the people have the same position before the law. But we must respect and recognize those differences. For example, we must respect to Muslim society in food assistance distribution and also must divide women and men who are not their "mahram" in evacuation location (shelter).

c. The need to monitor $=$ after/post natural disaster phase

In this phase, monitoring in assistance distribution, in rehabilitation, and in development recovery is the most important thing. It is essential to establish effective monitoring mechanisms, benchmarks, and indicators to ensure that the protection of the human rights of those affected by natural disasters, including those who are internally displaced, is effectively implemented. Furthermore, all disasters prevention, relief, and recovery should be assessed so as to evaluate whether those activities are being carried out by international human rights and humanitarian standards as outlined in the Operational Guidelines.

\section{Disaster Management Based On The Law Of Republic Indonesia Number 24 Year 2007 Concerning Disaster Management.}

Disasters occurred in Indonesia, whether a natural disaster or as a result of human error, resulting in losses either casualties or properties. Some disaster events such as ${ }^{31}$ :

1) 1.The biggest earthquake and tsunami occurred at the end of 2004 striking Nanggroe Aceh Darussalam province and part of North

2) Sumatera province with enormous casualties i.e. 120,000 deaths, 93,088 missing persons, and 4,632 injuries.

3) 2. Earthquake in Nias, North Sumatera occurred at the beginning of 2005 causing 128 deaths, 25 missing persons, and 1,987 injuries.

4) Earthquake in DI Yogyakarta and Central Java occurred on 27 May 2006 causing 5,778 deaths, 26,013 injuries as in-patients and 125,195 out-patients.

5) Earthquake and tsunami occurred on 17 July 2006 at the Java south coast (Pangandaran, Ciamis, Tasikmalaya, Garut, Banjar, Cilacap, Kebumen, Gunung Kidul and Tulung Agung) causing 684 deaths, 82 missing persons and 477 victims as in-patients out of 11,021 injuries.

6) Up to mid-2006 landslides occurred in Nanggroe Aceh Darussalam, West Sumatera, South Sumatera, West Java, Central Java, East Java, Bali and Papua with 135 deaths.

7) Flash floods happened in a row in mid-2006 in Sinjai district (South Sulawesi), flood in Bolaang district.

8) Mongondow (North Sulawesi), Gorontalo city (Gorontalo) Tanah Bumbu district and Banjar (South Kalimantan), Katingan (South-East Kalimantan).

\footnotetext{
${ }^{31}$ Departemen Kesehatan Republik Indonesia, Pedoman Teknis Penanggulangan Krisis Kesehatan Akibat Bencana, Panduan bagi Petugas Kesehatan yang Bekerja dalam Penanganan Krisis Kesehatan akibat Bencana di Indonesia, Jakarta, 2007. P.1.
}

34 HAS THE LAW NUMBER 24 YEAR 2007 ACCOMMODATED RECOVERY FROM PSYCHOLOGICAL IMPACT FOR VICTIMS? 
9) Mount Merapi in Central Java along the year 2006 showed increased activities causing four deaths, and 5,674 displaced persons with their health problems.

10) Since the beginning of 1999 vertical and horizontal conflicts occurred in Indonesia marked by social riots, such as in Sampit, Sambas West Kalimantan, Maluku, Aceh, Poso, Sulawesi, East Nusa Tenggara, Papua and various other areas and the impact was a large exodus of some of the population.

11) 10.Bali I and II bomb explosions, as well as a bomb blast in Jakarta areas, created health problem that also affected the social, politic, economic, legal and cultural aspect in Indonesia.

12) Technology failures such as the Petro Widada case in Gresik

13) Sidoarjo East Java hot mud burst.

The most disasters caused severe damage, loss, and grief which required a team of disaster mitigation to reduce the effect of it. Weak coordination among parties which involved in disaster management team often becomes a serious problem. The negative impact caused by weak coordination such as overlaps between the rescue teams in disaster areas, the absence of relief sector in disaster areas, late of assistance. Disaster Management is a part of national development in a series of disaster response activities before, during and after the disaster. All of these problems are considered to a weakness both in the implementation of disaster management and legal foundation because there are no laws that specifically deal with the disaster.

Recognizing this, the Indonesian government thought there should be a useful addition to regulation as a legal basis for disaster management and also useful to improve the coordination of disaster mitigation. On April 26, 2007, the Government of the Republic of Indonesia enacted Law No. 24 Year 2007 concerning Disasters Management. This law is expected to be a strong legal foundation for the implementation of disaster management, which in principle set the stage to include the pre-disaster, emergency response, and postdisaster.

In the Law No. 24 the year 2007 states that the implementation of disaster management is the responsibility and the authority of the central and local governments, which is implemented in a planned, integrated, coordinated, and comprehensive way. To create coordination between central and local government, the Indonesian government, based on the Law No 24 year 2007, established the National Agency for Disaster Management and Regional Disaster Management Agency. National Disaster Management Agency (BAKORNAS PB) is an inter-department coordination at the national level in disaster management. This organization was established by Presidential Decree No. 83 of 2005, led by the Vice President as Chairman, under direct responsibility to the President of the Republic of Indonesia. BAKORNAS PB task is to formulate and set policies, coordinate the implementation and provide standards and guidance for disaster management.

\section{Organization Structure of BAKORNAS PB}

Chairman: Vice President Republic of Indonesia

Vice Chairman: Coordinating Minister for People's Welfare

Members:

Minister of Finance

Minister of Energy and Mineral Resources

Minister of Communications

Minister of Public Works

Minister of Health 
Minister of Social Affairs

Minister of Communications and Informatics

Commander of the Indonesian National Army

Head of the Indonesian Police Force

Chief of the Indonesian Red Cross

Secretary: Executive Director of BAKORNAS PB

Regional Disaster Management Agency (SATKORLAK PB) is an organization at the provincial level chaired by the Governor who is responsible for organizing disaster response in his territory. The main task is to coordinate efforts of SATKORLAK PB disaster management by policies established by BAKORNAS PB. Implementation of disaster management in the emergency response phase is fully implemented by the National Disaster Management Agency and the Regional Disaster Management Agency. Disaster management agencies are comprised of elements from the steering and executive element.

National Disaster Management Agency and the Regional Disaster Management Agency have duties and functions including the implementation of disaster management in a planned and integrated coordination within their authority. Based on Article 33 of the Law No. 24 Year 2007, the implementation of disaster management consists of:

a. Pre-disaster, disaster management in the situation before the disaster happened or in a situation where there is a potential disaster.

b. Emergency response, disaster management during emergency response including rapid and appropriate assessment to the location, damage, and resources. Determining the status of emergency disaster - Rescue and evacuation of communities affected by disasters - Fulfilling the basic needs - protection of vulnerable groups - immediate recovery of vital infrastructure and

c. Post-disaster, including rehabilitation and reconstruction.

From the above three phases of disaster management, health care, psychosocial care and psychological recovery contained in the phase of emergency response and postdisaster.

The impacts of disaster are destruction, loss of property, injuries, death, and also psychological or psychiatric impact. Disaster which happened in a short time can result in a huge loss. Disasters do not only change the lifestyle of the people but also can alter the structure of society. Loss of property which is collected over the years, losing a family member or friend is a trigger factor for psychiatric disorders. The victims of disaster suffered psychological problems with the various types of psychological disorders. To overcome the psychological problems they need an extended period, for victims who suffered serious psychological problem need several years to recover his psychological condition, especially for vulnerable groups such as women, children, and elderly.

Psychological problems vary from mild to levels of acute mental health problems. In general, psychological responses of victims who experienced disaster can be divided into three main categories ${ }^{32}$ :

a. Normal psychological response, not requiring special intervention

b. Psychological distress or dysfunction response caused by stress or dysfunction, need psychological first aid

c. Distress or severe dysfunction requiring assistance for mental health professions.

Meanwhile, the psychological problems that often happened in disaster victims are:

1) Acute stress reaction 
2) Mourning Loss

3) Mental disorders that can diagnose

a. Depression (vs. sadness)

b. Anxiety disorder (vs. anxious)

c. adjustment disorders

d. Somato form disorders and

4) Alcohol substance abuse

5) Post-traumatic stress disorder (Post-traumatic stress disorder, PTSD)

6) Relapse/relapse of existing psychotic illness

7) Psychosomatic illness.

Treatment for the psychological problems of disaster victims often requires a long period, especially for victims who suffered serious mental disorder. In disaster management by Law No. 24 Year 2007, health interventions such as health care, psychosocial care and psychological recovery contained in the phase of emergency response and post-disaster. The need for mental health services in the event of disasters seldom meet adequate needs, one of the causes is the limited number of mental health workers in Indonesia, especially when disaster sites are located in remote areas where mental health professionals, as well as the supporting infrastructure, are not sufficient, moreover in some areas there are not ones at all.

In general, mental health problems in Indonesia can be explained as follows:

First, the low ratio of psychiatrists compared to the population of Indonesian, at 1:500.000 and number of psychiatric care facilities 1:30,000. This low numbers of psychiatrists and psychiatric care facilities are exacerbated by Indonesia's vast archipelago region. Indonesia's geographical situation increased difficulties for communities to access mental health services.

Second, the lack of mental health workers and a limited budget for mental health services ( $1 \%$ of the total health budget). The improvement of the mental health community does not only be done by psychiatrists but also can be done by other mental health workers. However, the comparison of the number of workers' mental health by the population of Indonesia is still very low ${ }^{33}$.

Third, the low number of psychiatrists staff and staff of mental health (psychologists, general practitioners who have additional expertise, known by the GP ++ ) as well as other difficulties obtaining access to mental health services caused by Indonesia's geographic circumstances resulted in higher costs for mental health services, especially for people who live in remote areas or inland.

The above conditions are exacerbated by the incomplete facility in community health center in Indonesia where not all of the Center provide psychological health care facility, so patients who need mental health services should go to a public hospital that is located in the provincial capital. Regarding recovery efforts of psychological impact of disaster victims, the National Agency for disaster management and Regional disaster management agency can provide social and psychological recovery activities. However, during this second phase, the mental health services have been completed. Otherwise, the efforts of mental health services to victims of disaster will automatically stop. Although mental health services to disaster victims remain, the service is not in the context of disaster management as referred to the Law of Disaster Management.

\footnotetext{
${ }^{33}$ According to Asia-Pacific Community Mental Health Development Project, Indonesia spends 1-2\% of the total health budget on mental health, with $97 \%$ allocated for mental hospitals, leaving a very limited budget for community mental health.
} 
Health care services are held on the initiative of the local government or nongovernmental organizations both local and foreign. This is the weakness of the law to overcome the disaster regarding psychological effects of disaster victims. Rehabilitation of damaged infrastructure is something measurable that the result can be planned well and can be seen in a particular time. This is very different from the recovery of the psychological impact of disaster victims which requires a long time, especially for victims who are experiencing acute mental health problems.

Based on this description, ideally, the recovery efforts of psychological impact of disaster victims do not stop even though the post-disaster phase has been declared finish. Easy access to mental health care facilities is needed by the victims of the disaster. It's necessary to provide mental health care facilities. Meanwhile, if there is no health community center around the disaster area, it needs to make health care facilities where mental health services integrated therein. So that disaster victims can receive mental health treatment, although the post-disaster phase has been declared complete.

The 1945 Indonesian Constitution states that Indonesia shall guarantee health care services for Indonesian people. Until now, the health care services have not been provided well; meanwhile, the national development requires good human resource quality, which has a productive life. One of basic needs that can support human resource improvement is the development in the area of health that every birth of human to the world bring basic rights that are rights for living healthily.

According to the preamble of 1948 WHO Constitution, health covers not only physical health but also mental health. In the preamble of 1948 WHO Constitution, it is stated that "Health is a state of complete physical, mental, and social well-being." Indonesian Law, No 36 of 2009 concerning Health, also adopts the similar point of view. It states that health is a prosperous state of physical, mental, and social well-being in helping everyone to have a productive life socially and economically. Therefore, it could be derived that mental health is part (integral part) of health in creating a good quality of life.

Mental health aspect does not get good attention, particular in low-income and middle-income countries, only a minority of treated people ( as low as $10,4 \%$ in Nigeria) receive adequate treatment ${ }^{34}$. Obsolescence in mental health sector is generated by matters, for example, lack of regulation, lack of fund, lack of skill, no political will, this condition makes the services in mental health worse and the number of people with mental disorder increasing significantly.

About the mental health of Indonesian Society, the Indonesian Government issued "National development Movement with the vision of Health" on 01 March 1999. Indonesia was one of the countries with the lowest ranks in the mental health services in Asia $^{35}$. Moreover, one group of people in the society whose rights are often being eliminated is a group of people with mental disorder. If the above-mentioned conditions were not changed, it would increase the marginalization of mental health services and, then, would increase the number of psychosocial problems in the society, such as suicide, addiction of substance psychoactive, violence, and chronic psychotic patients living in the street, though mental health directly affect progress toward achievement of many of the Millenium Development Goals (MDGs) ${ }^{36}$

World Health Organization (WHO) declares that mental health regulation in each country is one of the fundamental tools to ascertain the best mental health services and to protect the rights, especially the basic rights, of people with mental disorder. Since 1960, mental health has been regulated in some countries. It has been increasing in the last two

\footnotetext{
${ }^{34}$ Scale up services for mental disorders : a call for action, Lancet Global Mental Health Group, Vol. 370 October 6, 2007.

${ }^{35}$ Magazine Time edition 10 November 2003

${ }^{36}$ Op.cit.
}

38 HAS THE LAW NUMBER 24 YEAR 2007 ACCOMMODATED RECOVERY FROM PSYCHOLOGICAL IMPACT FOR VICTIMS? 
decades. In 2005, $78 \%$ of countries in the world had mental health regulations (WHO Atlas 2005). Since then, the number of countries who have mental health regulations has increased significantly. WHO always try to push every country to have mental health regulation.

\section{Conclusion And Recommendation}

1. Enactment of the Law No 24 Year 2007 concerning Disaster Management is the right decision considering many disasters in Indonesia; the law is one of a good way to prevent and handle the impact of the disaster.

2. The law is not only as a legal basis for disaster management but also as a guideline for disaster management team in addressing the impact of disasters.

3. Regarding mental health for disaster victims, Law of Disaster Management has provided the legal basis for mental health services for disaster victims, but the mental health services as mentioned in the legislation can not be performed optimally by the needs of disaster victims. This is because mental health services will be terminated along with the completion of the post-disaster phase.

4. Ideally in the Law of Disaster Management, especially for mental health problems, there are rules that regulate disaster victims who experience serious psychological illness in which mental health specialists suggest him to take further treatment, the victims are provided mental health services according to their needs, where such treatment is still within the framework of post-disaster. So even though post-disaster phase has terminated, the victims of disaster will still receive appropriate treatment.

\section{Bibliography}

Asplund, B. \& R. Romeo A ( 2003). Human Security, Human Development and the Millenium Development Goals, Jurnal Hukum Internasional (Indonesian Journal of International Law), Volume 1 Number 1 October 2003, ISSN: 1693-5594, Centre for International Studies, Faculty of Law University of Indonesia.

Departemen Kesehatan Republik Indonesia. (2007). Pedoman Teknis Penanggulangan Krisis Kesehatan Akibat Bencana, Panduan bagi Petugas Kesehatan yang Bekerja dalam Penanganan Krisis Kesehatan akibat Bencana di Indonesia.Departemen Kesehatan. Jakarta.

Djauhari Oratmangun ( 2003), Human Development and Human Security: A Journey Towards a Humane Global World, Jurnal Hukum Internasional (Indonesian Journal of International Law), Volume 1 Number 1 October 2003, ISSN: 1693-5594, Centre for International Studies, Faculty of Law University of Indonesia.

Michael L. Perlin. ( 2006). International Human Rights and Comparative Mental Disability Law: The Role of Institutional Psychiatry in the Suppression of Political Dissent.

Puspita, N.Y. (2010) Legal Analysis on Human Rights Protection in times of Natural Disasters and Its Implementation In Indonesia, Working Paper for Asian Law Institute Seminar, National University of Singapore.

Susanto, A.B. (2006), Disaster Management di Negeri Rawan Bencana, PT. Aksara Grafika Pratama, Jakarta.

Supancana, I.B.R ( 2005), International Disaster Response Law, Rules and Principles (IDRL) Programme of the International Federation of Red Cross and Red Crescent Societies (IFRCS), ASIL Insight, Indonesia.

Syahrial Loetan. (2003), Millenium Development Goal (MDG) dan Program Pembangunan Nasional di Indonesia, Jurnal Hukum Internasional (Indonesian Journal of International Law), Volume 1 Number 1, October 2003, ISSN: 1693-5594, Centre for International Studies, Faculty of Law University of Indonesia. 